\title{
VOTERS' ROLL CRISES AND THE NEED FOR ELECTORAL REFORMS IN SOUTH AFRICA
}

\author{
Raynauld D Russon \\ Dr RD Russon is the Director of the Institute \\ of Commerce and Management SA \\ email: russonray@yahoo.com
}

\begin{abstract}
This paper considers the implications of the Constitutional Court ruling that declared the 2013 Tlokwe by-elections unconstitutional. This ruling was because the voters' roll did not contain the addresses of voters as required by electoral legislation and it has cast a shadow on the credibility of elections in South Africa. The Constitutional Court gave the Electoral Commission until the end of June 2018 to correct this problem which affects over 10 million voters. The question that this paper discusses is whether the Electoral Commission will find a solution to this conundrum before the national general elections scheduled to take place in 2019. This is especially urgent because the Electoral Commission has already indicated its incapacity to perform this task in the face of inadequate resources. The paper also looks at the nature of the problem regarding the voters' register and the voting district within which it is premised. In an attempt to find a solution to this problem the author undertook a small survey to establish whether political parties used the addresses of voters to conduct their campaign work. The paper concludes by suggesting electoral reforms that may resolve the problem of the voters' roll and improve the overall management of elections in South Africa.
\end{abstract}

Keywords: credibility; integrity; voters' roll; voting district; electoral reform; Electoral Commission; Constitutional Court

\section{BACKGROUND}

On November 302015 the Constitutional Court (Concourt) of South Africa made a landmark ruling declaring that by-elections conducted in Tlokwe local municipality had not been free or fair. These elections had been held on 12 September in Ward 18 and on 10 December 2013 in Wards 1, 4, 11, 12, 13 and 20. The reason for the decision was that the voter register was deficient and lacked 
the addresses of some voters. The Independent Electoral Commission (IEC) approached the Constitutional Court in 2016 in an attempt to get clarity on the far-reaching implications of this judgement. The Constitutional Court reaffirmed its previous decision but gave the Commission a temporary reprieve for the 2016 local elections. This has placed the IEC in the near-impossible situation of having to retrieve the addresses of millions of voters in order to make the voters' roll consistent with electoral laws and constitutional requirements.

The Electoral Act (73) of 1998 (as amended) requires the chief electoral officer to provide political parties with copies of the voters' roll that include voters' addresses. By its own admission, the IEC stated in court papers to the Constitutional Court that the national common voters' roll is missing 12.2 million addresses.

\section{INTRODUCTION}

Chapter 9 of the Constitution establishes state institutions, including the Electoral Commission, that support constitutional democracy. Its functions are described in the Constitution as being: '[to] manage elections of national, provincial and municipal legislative bodies in accordance with national legislation and to ensure that elections are free and fair' (Constitution Act 108 of 1996).

The national legislation referred to in the Constitution include the Electoral Commission Act 51 of 1996, the Electoral Act 73 of 1998, the Local Government Municipal Structures Act 117 of 1998, and the Local Government Municipal Electoral Act 27 of 2000. The Electoral Commission Act establishes the Electoral Commission of South Africa and spells out its powers and responsibilities. The Electoral Act outlines the manner in which elections are managed at national and provincial level. The Local Government Municipal Structures Act defines the types of municipalities in South Africa whilst the Local Government Municipal Electoral Act deals specifically with the manner in which local elections are conducted.

The Bill of Rights in the Constitution (1996) is also instructive and relevant for our discussion on this subject. Political rights as prescribed in the Bill of Rights, especially 19(2), state that 'Every citizen has a right to free, fair and regular elections for any legislative body established in terms of the constitution'.

This paper begins by looking at the nature of the problem of addresses on the voters' roll and proceeds to look specifically at the Tlokwe case and the resultant Constitutional Court judgements. It then explores possible ways to resolve this problem.

\section{THE PROBLEM}

On his return from observing elections in the United Kingdom in 2001, Tony Leon, then leader of the Democratic Alliance, brought back the idea of including 
addresses in the voters' roll to assist political parties in canvassing voter support. As the IEC supported the idea, he immediately approached Parliament with a proposal to amend the Electoral Court. Parliament invited the Electoral Commission to make submissions on this proposal which the Commission did not oppose. Consequently the Electoral Act was amended by the Electoral Laws Amendment Act 28 which introduced Section 16(3) and (4) that came into effect on 17 December 2003'.

Adding addresses to the voter register is not only a laborious exercise but is also very costly. For developing countries with limited resources this is a major challenge. This is further compounded by the fact that the majority of the population resides in the countryside where, unlike the towns and cities, there are no formal addresses. South Africa is no exception to this problem. In addition it has the bigger problem of informal settlements in the urban areas as part of the legacy of apartheid. Informal settlements are sprawled all over the urban areas and exist as a survival strategy for the many poor families who have migrated from the countryside in search of employment. Many such informal settlements do not even have names, let alone street names and numbers. Capturing an address as a unit of residence for a specific homestead in such settings is impracticable.

Adding to the problem of addresses on the voters' roll is the issue of the voting district, also a creation of the IEC and formalised into law. The voting district is a small unit comprising not more than 1500 voters in a given area. It is not an electoral constituency within which votes are consolidated to return specific results for a specific political outcome; but it is an administrative unit designed to assist the Commission in locating voting stations. The boundaries of voting districts are fluid and at times impossible to discern, particularly in densely populated areas and informal settlements. This has resulted in many people registering in incorrect voting districts because voters often go to the closest voting station to register even if it falls in a different voting district from where they live. This problem is magnified in densely populated areas such as downtown Johannesburg where one block of flats could easily qualify as a voting district. To compound the problem the IEC decided to criminalise registration in an incorrect voting district thus rendering millions of South Africans criminally liable. This is a perfect example of a decision by an electoral management body that can have what Elklit and Stephan (2001) described as an indelible effect on the credibility of elections. The national common voters' roll is a list of all the eligible voters in an election and is therefore one of the cornerstones of election

1 Author's note: I speak on this subject with reasonable insight because I was the Chief Director responsible for the Voters' Roll at the Electoral Commission during this period. Suffice it to state that I opposed this idea of adding addresses in the voters' roll and also the idea of making the voting district a legal entity. 
credibility. The compilation of the voters' roll requires extra caution to ensure that no eligible voter who wishes to exercise his or her right to vote is denied such a right.

\section{TLOKWE BY-ELECTIONS}

The infamous case of the Tlokwe by-elections that began in August 2015 has cast a dark shadow on the credibility of South Africa's elections, following the Constitutional Court ruling that deemed the Tlokwe by-elections unfair and unfree. The following is a summary taken from the Constitutional Court judgement (Constitutional Court 2015):

Towards the end of 2013 eight (8) members of the Tlokwe local municipality (Xolile David Kham, Johannes Sesing Johnson, Aaron Pasela Mhlope, Johanna Shonu Xaba, Ntombi Beauty Dikube, Dikeledi Catherine Molefe, Velilele James Zicina, Khotso Ratikoane) broke away from the African National Congress and decided to contest the byelections as independent candidates calling themselves 'independent candidates united against corruption'. They contested elections in various wards on various dates between August and December but were unsuccessful. ‘The first by-election was on 7 August 2013 in ward 9 where one of the breakaway councillors contested but lost. The second by-election was held in ward 18 on 18 September 2013, where Mr Kham, one of the breakaway councillors, was a candidate and also lost. He lodged a complaint with the IEC in terms of section 65 of the Local Government: Municipal Electoral Act, stating that ineligible voters had been registered and allowed to vote in Ward 18 even though they did not reside therein. The IEC dismissed the complaint. The remaining six candidates were to contest by-elections in wards $1,4,11,12,13$ and 20 scheduled to take place on the 23 October 2013. They lodged objections to the IEC regarding these elections and a fresh date was fixed for 11 December 2013. They also objected to this date complaining that they received the segments of the voters' roll late i.e. on the $4^{\text {th }}$ of December instead of the $11^{\text {th }}$ as stated in the elections time table. In addition the segments that they received did not contain the addresses of voters as required by the Act. The IEC rejected their objection. The candidates approached the Electoral Court requesting a postponement but due to the death of former President Mandela the court could not sit to hear the matter and the elections proceeded. All these candidates 
lost at the polls and subsequently approached the Electoral Court for an order to set aside the results of these by-elections.

It is also important to note that the IEC conducted its own independent investigation in the matter. It found that there were indeed problems with the voters' roll and that voters had voted in wards where they were not ordinarily resident. However, the IEC concluded that this number was minuscule and could not have changed the outcome of the results. On 19 March 2015 the Electoral Court confirmed this position and dismissed the case of the applicants who then approached the Constitutional Court, which ruled as follows:

a) It is declared that the by-elections conducted in the Tlokwe Local Municipality on 12 September 2013 in ward 18 and on 10 December 2013 in wards 1, 4, 11, 12, 13 and 20, were not free and fair.

b) The outcome of those by-elections is set aside and fresh by-elections are to be held in terms of section 25 of the Local Government: Municipal Structures Act 117 of 1998.

c) It is declared that when registering a voter to vote in a particular voting district after the date of this order the Electoral Commission is obliged to obtain sufficient particularity of the voter's address to enable it to ensure that the voter is at the time of registration ordinarily resident in that voting district.

d) It is declared that in all future municipal elections or byelections the Electoral Commission is obliged in terms of section 16(3) of the Electoral Act 73 of 1998 to provide all candidates in municipal elections, on the date on which they are certified, with a copy of the segment of the national voters' roll to be used in that ward in that election including the addresses of all voters, where these addresses are available.

Constitutional Court 2015, para. 5

This judgement had a far-reaching effect on the entire voters' roll and the credibility of past and future elections. The court however made an important addition to its ruling in order to cover the possible ramifications of its judgement on previous elections. It stated that the ruling was not retrospective and therefore would not affect the validity of any election or by-election held prior to the date of the order (Constitutional Court 2015, para. 6).

This judgement sent a shiver of unease through the corridors of the IEC. The concern was whether it would be able to administer the local elections scheduled for 2016, because the judgement effectively meant that the IEC had to find the 
missing addresses for a large number of voters in the voters' roll. This was not only a very long process but also a very costly exercise. It then approached the Constitutional Court for either an appeal or alternatively to seek clarification of the judgement. In its papers the IEC indicated that it needed a few years to correct the voters' roll as well as a considerable sum of money, and that the exercise would not be completed in time for the local elections scheduled to take place in August 2016. Whilst awaiting the Constitutional Court ruling the IEC went ahead and proclaimed the results of the 2016 election. In doing so they certified a voters' roll that was technically incomplete and also subjudice as it was still pending in the Constitutional Court. One political party (Shosholoza Progressive Party) that had been disqualified from the elections for failure to submit candidates in time, approached the Electoral Court and tried to stop the process. They argued that the IEC had acted in contempt of court by certifying a voters' roll that had been deemed invalid and unconstitutional. The Electoral Court surprisingly dismissed the matter.

The Constitutional Court finally reached its verdict on the application by the IEC and confirmed its earlier decision, namely that the national common voters' roll lacking the addresses of certain voters was invalid and inconsistent with the rule of law.

The following is a ruling of the Constitutional Court (2016 paragraphs 5-9):

5. The Electoral Commission's failure to record all available voters' addresses on the national common voters' roll is inconsistent with its rule of law obligations imposed by section 1(c) of the Constitution and invalid.

6. The declaration of invalidity in paragraph 5 is suspended and:

6.1. The duty of the Electoral Commission to record all the available addresses of voters on the national common voters' roll for the purpose of the August 2016 local government elections is, except for the Tlokwe Local Municipality, suspended.

6.2. The Electoral Commission must by 30 June 2018 have obtained and recorded on the national common voters' roll all addresses that were reasonably available as at 17 December 2003.

7. The order in paragraph 6 does not apply to local government byelections.

8. At six-monthly intervals calculated from the date of this order, the Electoral Commission must file a report with this Court, setting out: 8.1. The number of outstanding post-December 2003 addresses it has since obtained and recorded on the national common voters' roll; 8.2. The number of post-December 2003 addresses still outstanding; 
8.3. The steps taken and to be taken to obtain outstanding postDecember 2003 addresses;

8.4. Any other matter it may consider necessary to report on.

9. The Electoral Commission must pay the costs of appeal and application for direct access of the independent candidates, the Democratic Alliance and the Inkatha Freedom Party, including the costs of two counsels.

To save the day, the Concourt invoked section 172(1) of the Constitution, which reads:

When deciding a constitutional matter within its power, a court-

(a) must declare that any law or conduct that is inconsistent with the Constitution is invalid to the extent of its inconsistency; and

(b) may make any order that is just and equitable, including-

(i) an order limiting the retrospective effect of the declaration of invalidity; and

(ii) an order suspending the declaration of invalidity for any period and on any conditions, to allow the competent authority to correct the defect (Constitution Act 108 of 1996).

The important point here is that the Constitutional Court did not backdate the suspension of the invalidity to cover the actions of the IEC in certifying an invalid national common voters' roll for the 2016 local elections. It is my contention that the local elections of 2016 were unfair and unfree because they were based on an invalid voters' roll certified by the IEC before the Concourt judgement. Thus that judgement did not grandfather the process to legitimise or validate the certification of the voters' roll.

This vindicated the application by the Shosholoza Progressive Party to the Electoral Court i.e. that the IEC had certified a national common voters' roll that was invalid because it lacked addresses. In addition, it also included the Tlokwe segment which was now specifically excluded by the Concourt judgement. The Constitutional Court made reference to this point in its ruling on paragraph 84 when it stated that the IEC would not be able to certify a voters' roll that lacked 12.2 million voters. The irony is that the IEC had already certified this voters' roll even before the Constitutional Court made its ruling, which stated as follows:

I (Justice Madlanga J.) have spelt out the difficult position in which the IEC finds itself. Ordinarily, it would be easy to dismiss its request on the basis that the situation in which it finds itself is of its own making. 
But the reality is that - unlike litigation between private individuals where a party's fault would affect it and it alone - here if something were to go wrong, the implications are serious and likely consequences dire. To put it bluntly, the IEC would not be able to certify the voters' roll for want of the 12.2 million addresses. Without a certified voters' roll, there can be no elections.

Constitutional Court 2016 para. 84

\section{POSSIBLE SOLUTIONS}

\section{Remove the voting district}

The voting district has compounded the problem of the voters' roll because millions of people have registered in the wrong voting districts. This may not have direct consequences for election results so long as the wrong voting district remains within the correct ward. It is only when people cross the ward boundaries to register in incorrect voting districts that this becomes consequential for election results, especially for municipal elections. It is only when people violate the electoral district boundary such as the municipal ward that electoral fraud can occur. Voters bussed between voting districts within the same ward would not affect election results. It is only when voters are bussed across ward boundaries that election results can be affected. In an attempt to correct this anomaly and to reduce possible electoral fraud the IEC criminalised registration in the wrong voting district. In 2016 the IEC released the following statement: 'The Electoral Commission reminds voters that it is a criminal offence to register where they are not ordinarily resident and it will not hesitate to pursue criminal charges against any person found to have violated this or who may have encouraged others to violate this provision' (Electoral Commission 2016). The voting district has also rendered the technical accuracy and validity of the voters' roll problematic.

Our political system has three tiers of government i.e. local, provincial and national. Each tier has a specific constituency from which candidates are elected; these are called electoral districts and each of them has a pertinent segment of the voters' roll.

For the National Assembly, the country is the electoral district and the voters' roll is the entire national common voters' roll. The accuracy of the voters' roll for this electoral district is arguably $100 \%$. This means that every South African with the correct documents is eligible to vote as long as they can prove that they live in South Africa or are South African citizens. There are no cross-boundary problems where people in one electoral district cross the boundary to vote in another.

The second tier legislative structure is the National Council of Provinces whose members are elected from the provinces. The voters' roll used here is the 
provincial segment. South Africa has nine provinces meaning that there are nine electoral districts for this election. Here there are cross-boundary problems in the registration of voters because provincial boundaries have no physical fences, so people may cross a boundary unknowingly and register in a different province. In some instances communities have deliberately crossed boundaries to register as a form of protest because they prefer to be in that province. This happened for example in the areas between Northwest Province and Gauteng, and Limpopo and Mpumalanga. To resolve this problem the IEC introduced targeted registration specifically in order to target cross-boundary areas and clean up the voters' roll. In this instance only nine boundaries have been identified.

The third tier legislative structure is the municipality which uses the municipal segment of the voters' roll as the primary constituency. However, our electoral system at local level combines proportional representation and first-past-the-post winners. Thus the municipality is further broken down into wards, making the ward the smallest constituency in our electoral system. South Africa has more than 250 municipalities of various sizes and configurations and thousands of wards. Cross-boundary registrations between municipalities are very common, as are those between wards. The targeted registration drive entails a visit to all the municipal boundaries and more than 4200 ward boundaries. Technically, this means that the accuracy of the voters' roll declines at every tier, making the ward segment the least accurate. In addition, the IEC introduced the voting district which is not an electoral constituency but an administrative unit. This action created more than twenty thousand new boundaries (22 600 in 2016) and was made without any anticipation of the extent of the problem. The voting district should remain an administrative unit used only to determine the location of voting station. This is to ensure that they are proportionate to voting populations at given times and given spaces but is fully cognisant of the fact that voting numbers are a moving target. From an operational point of view, this means that targeted registration will be done around the electoral districts only, instead of attempting to clean up tens of thousands of boundaries. The simple solution is to use the voting station as a control point i.e. once registered at a voting station the voter can vote only there and nowhere else. To manage numbers in each voting station for the purposes of logistical supplies, census data can be used to plot voting stations.

The conclusion is simple; the smaller the constituency the more crossboundary violations will occur, especially with informal settlements and rural areas where no formal addresses exist. In conducting its own investigations into the Tlokwe matter the IEC found that more people had registered outside their actual voting districts than the complainants had indicated. To try and correct this problem the IEC chose to remove these additional registrations from the 
voters' roll, thus effectively disenfranchising those voters. Disenfranchising voters because they are registered in an incorrect voting district, an entity that has little significance in election outcomes, is more problematic. The solution is to remove the voting district as a legal unit in our elections and use it for planning purposes only.

\section{Remove the requirement of addresses on the voters' roll}

The idea of capturing voters' addresses in the voters' roll adds insult to injury. The technical accuracy of the voters' roll was already significantly compromised by introducing and legalising the voting district. The address is an important entity to place a voter in the correct segment of the voters' roll and the correct electoral district/constituency so that they can exercise their right therein. But I contend that it is not the responsibility of an electoral management body to provide addresses to political parties for the purposes of pre-election canvassing. Although our Constitution defines the role of the IEC in promoting democracy, it can also be argued that this role merely refers to conducting a free and fair election and that the role of finding voters for political parties lies outside the scope of the elections management body. The extension of the IEC mandate to include this role has, it can be argued, compromised the very essence of the primary role that the IEC was established to perform; i.e. to deliver free and fair elections as proven by the Tlokwe matter.

From the above discussions it is clear that the solution to the problem of the voters' roll lies in amending the legislation to remove the requirement of addresses in the voter's roll. This would be the quickest and most cost-effective manner to correct the voters' roll and improve its technical accuracy. Other options would be to use modern technology like geographic positioning systems (GPS) that would accurately locate addresses. This would require a huge outlay of resources because it would mean door-to-door visits to capture addresses. In many places like the informal settlements and rural areas officials would have to create the addresses on the GPS platforms in order to capture the exact address name on the voters' roll. This is indeed a mammoth task. In its June 2017 six-monthly reports to the Constitutional Court (as required by the judgement) the IEC conceded that the process was very slow. A meagre $1 \%$ of addresses had been updated in the period between December 2016 and June 2017, and an amount in excess of R300 million will be required to complete this task by the required date of 30 June 2018 (Mail and Guardian 27 July 2017).

The argument that addresses on the voters' roll assist political parties in their campaigns cannot be proven; and even if this is the case, the cost of this exercise outweighs the benefits for our democracy. 
I conducted the following small survey (sample 90) in three communities in Midrand to check if indeed political parties visited voters at their homes to canvass for votes using the addresses provided in the voters' roll.

\section{Questions}

1. Were you contacted by any political party agent during the local elections and how?

2. Did they know your name or did they ask for any specific person by name when they arrived?

3. What did the party agents want or ask you to do?

My findings are listed in Table 1 below:

Table 1

Percentage use of addresses to canvass support by political parties

\begin{tabular}{|l|c|c|c|c|c|c|c|c|c|c|}
\hline Area & \multicolumn{9}{|c|}{ Answ } \\
\hline & $\begin{array}{l}\text { Contacted } \\
\text { by party } \\
\text { agents }\end{array}$ & \multicolumn{3}{|c|}{ How } & \multicolumn{2}{c|}{$\begin{array}{c}\text { Did they } \\
\text { know your } \\
\text { name }\end{array}$} & \multicolumn{3}{|c|}{$\begin{array}{c}\text { Reason for visit or } \\
\text { contact }\end{array}$} \\
\hline & Yes & No & Visit & Letter & Phone & Yes & No & Vote & Register & Other \\
\hline $\begin{array}{l}\text { Rabie } \\
\text { Ridge }\end{array}$ & 23.3 & 76.6 & 16.6 & 0 & 6.6 & & 100 & 0 & 0 & $\begin{array}{c}23.3 \\
\text { Free } \\
\text { T-shirts }\end{array}$ \\
\hline $\begin{array}{l}\text { Oliven- } \\
\text { hout- } \\
\text { bosch }\end{array}$ & 6.6 & 82 & 3.3 & 0 & 3.3 & & 100 & & 6.6 & None \\
\hline $\begin{array}{l}\text { Vorna } \\
\text { Valley }\end{array}$ & 26.6 & 73.3 & 0 & 10 & 16.6 & & 100 & 13.3 & 13.3 & None \\
\hline Total $\%$ & 18.8 & 64.4 & 6.6 & 3.3 & 8.8 & & 100 & 4.4 & 6.6 & 7.8 \\
\hline $\begin{array}{l}\text { Total } \\
\text { Actual }\end{array}$ & 17 & 58 & 6 & 3 & 8 & & 90 & 4 & 6 & 7 \\
\hline
\end{tabular}

The findings in the above table indicate the following:

1. A small number of voters were directly contacted by political parties $(18.8 \%)$ and an even smaller number of voters were paid a physical visit by political party agents $(6 \%)$. The largest number of people visited in Rabie Ridge explained that one political party visited them to provide them with free t-shirts. This was obviously a random process that was not based on whether or not people were registered. 
In fact two people who received t-shirts confirmed that they were not registered to vote.

2. Only $3.3 \%$ of voters who were contacted by political parties were contacted by mail. In probing voters about the type of mail received, they all confirmed that the mail received in their mail boxes was in the form of pamphlets which were not specifically addressed to an individual. This is the only and closest evidence to demonstrate that addresses could have been used to contact voters. The fact that random pamphlets were used means that this evidence does not support the argument for voters' roll addresses.

3. The fact that party agents did not know the names of the people they visited is damning evidence proving that addresses in the voters' roll are not used by political parties to canvass votes.

It is a common practice across the political spectrum that political parties often use community halls to address voters. If they do door-to-door campaigns to canvass support they merely walk around knocking on doors and talking to people, some of whom are not even registered to vote. The current trend amongst political parties is to use social media e.g. SMS, or text messaging, to communicate with voters.

\section{Electoral reform}

The voters' roll conundrum provides an important trigger factor for the IEC to undertake a comprehensive electoral reform process aimed at improving electoral processes.

Electoral reform is an integral part of democratic development. In broad terms, electoral reforms are undertaken to improve the electoral process by promoting the electoral rights of citizens and by operationalizing key principles such as impartiality, inclusiveness, transparency, integrity and accuracy. Continuous reflection, reform and adaptation of the legal framework governing electoral processes that are based on experiences, reviews and assessments are necessary in both old and new democracies.

IDEA 2014, p. 5

IDEA (2014) also identifies three key areas of electoral reform i.e. political, administrative and legal; and it is my contention that all three areas need to be looked at by the IEC. However, of top priority for the subject in question would be the following reforms: 
1. Amend the section 16(3) of the Electoral Act to remove the requirement of addresses in the voters' roll. It is because of this provision that the Concourt ruled that the voters' roll was unconstitutional because it violated the law written to promote a constitutional principle. If this law is amended then the violation falls away.

To assist political parties in their campaign work, the IEC may be requested to provide a list of the available addresses of voters on a sheet separate from the voters' roll. This would protect the integrity and constitutionality of the voters' roll. The magnitude of collecting the 12.2 million outstanding addresses is insurmountable and thus the IEC had requested a four-year moratorium to rectify this problem. Unfortunately this was rejected by the Constitutional Court and the IEC was given a period of only two years. This period is insufficient to collect 12.2 million addresses especially considering the fact that the IEC had failed to perform this task in over a decade, that is from 2003. To enforce this the Concourt issued a supervisory order forcing the IEC to provide six-monthly progress reports. Given the time span and available budget it is my contention that the IEC will resort to the tactic of removing voters from the roll, as happened in Tlokwe, in an attempt to comply with this requirement. I view this as more serious than having a voters' roll without addresses because the effect is to disenfranchise the voter and is thus contrary to the right to vote as enshrined in the Constitution. The Concourt also discussed the possibility of amending the Act but was not able to enforce it because of time constraints and the fact that Parliament was not party to the matter, as stated below:

During argument, the possibility of a referral of the matter to Parliament to resolve it by, for example, passing legislation that may suspend the applicability of section 16(3) was raised. I see at least two problems with this. First, Parliament is not a party before us. One has no idea what its reaction might be to an expectation that it should do something. The operative word is "expectation", not "order", because I do not see how - in these circumstances - we can make an order against a nonparty. Second, it is just too late in the day to expect that Parliament will enact that legislation in time for the conduct of the elections within the constitutionally set deadline. This is complicated by the fact that after Parliament, the legislation will have to be presented to the President for him to play his role in terms of section 79 of the Constitution. To my mind, the parliamentary route does not remove the looming risk. 
The Constitutional Court in its ruling on the matter made a profound observation when it stated that the absence of addresses may, and not will, result in elections being unfair: 'The absence of addresses might - not will - result in elections being unfair' (Constitutional Court 2016 para. 19).

It may therefore be necessary for the IEC to undertake a wider study with a larger sample to test whether political parties are indeed using addresses to canvass for voter support. If this is not the case the IEC should be freed from the costly and arduous process of providing addresses on the voters' roll. Following the amendment of the Electoral Act, the IEC could approach the Constitutional Court to review its decision on the Tlokwe matter. I am certain that the court would view this in a positive light because the IEC would no longer be in breach of an Act of Parliament and thus of the Constitution. Reading the Constitutional Court judgement, Justice AJ Wallis makes reference to a similar study when he states that:

I can see force in the contention that in order for an election to be fairly conducted it is necessary that the participants have available to them not simply a list of voters' names and identity numbers but also some means of identifying and contacting them, of which the voters' addresses is the most obvious. But it is unnecessary in the light of section 16(3) to reach a firm conclusion on this question and I would hesitate to do so without further enquiry into the electoral systems of other democratic countries and the requirements for the preparation of voters' rolls there.

Constitutional Court 2015, para. 94

2. Remove the voting district as a legal entity and keep it as an administrative unit and thus decriminalise the millions who are registered outside these imaginary boundaries called voting districts. Increase the effort on targeted registrations on ward boundaries as the smallest units of electoral districts to clean up cross-boundary registrations.

3. The traditional paper voters' roll used during elections must be replaced by an electronic voter register that functions like a speed paypoint. The voter's identity card or book is scanned and a slip is printed and issued to the voter, who then presents it to an official who files it away before issuing a ballot paper. This would provide the paper trail that political parties have been concerned about.

4. The ballot paper must be replaced with an electronic voting machine as is the current trend internationally. It is disappointing that one of 


\begin{abstract}
Africa's leading economies is still stuck in the past in the manner in which it delivers its election results. The manual process is laborious, exhausting and takes too long to return results. Election officials are overworked and some stay without sleep for more than 24 hours, working to count ballot papers. This is unfair labour practice in a time when we have the appropriate alternative technology at our disposal. By using electronic voting machines, results would be counted and verified in a matter of minutes. If stations close at 9 or $10 \mathrm{pm}$ staff finish and retire to their homes to rest; but in the current state they stay up counting ballots for hours and even days without sleep.
\end{abstract}

\title{
CONCLUSION
}

If the above mentioned proposals can be considered, the burden of the IEC to provide addresses would be relieved at the stroke of a pen with the additional benefit of a substantial monetary saving.

Electoral legitimacy and the integrity of the electoral process are of enormous importance in South Africa. It is appropriate to end this paper with the following quotation from the Constitutional Court.

Electoral legitimacy and the integrity of the electoral process are of enormous importance in South Africa. Many people, in many different ways, struggled and fought to secure the right to vote for all people in South Africa. It was a right denied to the vast majority of this country's citizens. Many devoted their lives to the struggle for democracy. Others were imprisoned, banned, harassed and exiled. No-one who was in, or has seen photographs of the patient queues that waited for hours to cast their votes in the first democratic election can have any doubt that the right to vote is a precious one for all South Africans. The struggle of all those who worked to bring democracy to this country is properly honoured when we conduct free and fair elections to determine the will of those who now have the right to vote. It is vital therefore that we are jealous of the privilege so hardly won. In determining a just and equitable remedy, where an election has been held not to be free and fair, these considerations must form the backdrop to the performance of the Court's role as the guardian of the Constitution and the IEC's performance of its obligation to ensure free and fair elections. 


\section{- REFERENCES}

Electoral Commission v Mhlope and Others [2016] ZACC 15, http://www1.saflii.org/ $\mathrm{za} / \mathrm{cases} / Z A C C / 2016 / 15 . p d f)$ [8 March 2017]

Electoral Commission 2016, Preparations for the Tlokwe by-elections, http://www.gov. za/speeches/preparations-tlokwe-elections-18-feb-2016-0000 [15 March/2017]

Elklit, J \& Reynolds, A 2001, 'Analysing the Impact of Election Administration on Democratic Elections', Representation, vol. 28, pp. 3-10.

IDEA 2014, Electoral Law Reform: Insight into the Role of EMBs and Approaches to Engagements; a Policy Paper, http://www.oldsite.idea.int/publications/electorallaw-reform-in-africa/loader.cfm?csModule=security/getfile\&pageID $=66792$ [22 February 2017]

Kham and Others v Electoral Commission and Another [2015] ZACC 37), http://www. saflii.org/cgi-bin/disp.pl?file=za/cases/ZACC/2015/37.html\&query $=\% 20$ kham, [18 March 2017]

Mail \& Guardian 27 July 2017, 'Frustrated IEC needs R300m to collect missing addresses for voter registration', (https://mg.co.za/article/2017-07-2500-frustrated-iec-needs-r300m-for-voter-registration-to-collect-missingaddresses) [6 August 2017]

South Africa 1996, Constitution of the Republic of South Africa, Act 108 of 1996, http:// www.acts.co.za/constitution_of_/constitution_of_the_republic_of south africa [22 February 2017] 